\title{
Influence of wind events on the transport of early stages of Micropogonias furnieri (Desmarest, 1823) to a subtropical estuary
}

\author{
Monique O. Franzen ${ }^{1}$, José H. Muelbert ${ }^{1}$ \& Elisa H. Fernandes ${ }^{2}$ \\ ${ }^{1}$ Laboratório de Ecologia do Ictioplâncton, Universidade Federal do Rio Grande, Rio Grande, Brazil \\ ${ }^{2}$ Laboratório de Oceanografia Costeira e Estuarina, Universidade Federal do Rio Grande \\ Rio Grande, Brazil \\ Corresponding author: Monique O. Franzen (m.franzenmaia@gmail.com)
}

\begin{abstract}
As all coastal environments, the Patos Lagoon Estuary (PLE) is an important habitat for the early stages of the life cycle of many marine organisms. Little is known, however, about how larvae respond to the estuarine dynamics because this study is complex. An actual way to investigate fish eggs and larvae dispersion is to use "Individual-Based Models" (IBM). Here, an IBM is used to study the wind influence on the transport of fish eggs and larvae of Micropogonias furnieri in the PLE. Circulation patterns were generated and extracted from TELEMAC-3D hydrodynamic model and simulated in an IBM. Results demonstrated that the transport of M. furnieri larvae to the PLE is maximized during periods of southerly winds. During northerly winds, on the other hand, larvae are advected off the estuary. This study revealed that the wind-driven estuarine dynamics mainly modulate the transport variability of eggs and larvae and it could have consequences for M. furnieri's recruitment.
\end{abstract}

Keywords: Micropogonias furnieri; fish eggs and larvae; hydrodynamic transport; hydrodynamic estuarine; biophysical model; recruitment

\section{INTRODUCTION}

Estuaries and other coastal environments are important habitats for early life stages of many marine organisms, when they need to be transported to these nursery regions to develop and grow (Beck et al., 2001). Therefore, these species are often called estuarinedependent (Able, 2005). Within this context, the Patos Lagoon Estuary (PLE) offers protection against predators and an important feeding ground for larvae and juveniles (Muelbert \& Weiss, 1991; Haimovici et al., 1996; Sinque \& Muelbert, 1997; Vieira \& Castello, 1997). The growth of these organisms within the estuary is vital to the maintenance of local fishing activity along the southern Brazil coast (Chao et al., 1985; D'Incao, 1991), which is one of the main fishery grounds of the Southwest Atlantic (García et al., 2001). Thus, the identification of the main habitats used by species during their life cycle, and the influence of en- vironmental variables in the connectivity between these habitats is essential for the application of management practices focusing on the conservation of ecosystems and fisheries stocks (Costa et al., 2014).

Micropogonias furnieri (Desmarest, 1823) is a euryhaline fish species that use different coastal environments during its life cycle (Vazzoler, 1991; Costa et al., 2014). The wide range of its geographical distribution, from Western Atlantic in Gulf of Mexico $\left(20^{\circ} \mathrm{N}\right)$ to Argentina $\left(41^{\circ} \mathrm{S}\right)$ (Volpedo \& Cirelli, 2006; Froese \& Pauly, 2017) and an effective osmoregulatory system (Diaz et al., 2008) allows this species to use a variety of habitats, such as estuaries, bays, coastal lagoons and the inner continental shelf. Spawning occurs in the inner platform near estuarine semienclosed systems, and young fish uses estuarine areas as nursery grounds once are safe and productive habitats for its development. When they reach larger sizes, the fish moves to spawn in the inner platform

Corresponding editor: Guido Plaza 
(Vazzoler, 1991; Costa \& Araújo, 2003; Franco et al., 2018).

M. furnieri occurs year-around in the PLE, from its early stages (Muelbert \& Weiss, 1991) to a size range of 10 to $>250 \mathrm{~mm}$ of total length (TL) (Vieira, 2006). In Brazil, it is one of the most important fisheries (Lasta \& Acha, 1996; Vasconcellos \& Haimovici, 2006) with annual catches over 40,000 $\mathrm{t}$ (MPA, 2010). The species ranks first in number in bottom trawl samples, it is also among the four dominant species in beach seine samples (Vieira, 2006), and depends on the PLE ecosystem to successfully recruit and maintain the adult population that supports local traditional fisheries (Abreu \& Castello, 1997; Odebrecht et al., 2010; Albuquerque et al., 2012).

The M. furnieri population from southern Brazil spawn in the coastal region adjacent to the mouth of the PLE (Castello, 1986; Ibagy \& Sinque, 1995) during warm periods of the year (Vazzoler, 1991; Costa et al., 2014) and its transport and migration towards the estuary (Shaw et al., 1988) are dependent upon coastal circulation.

The circulation in the PLE is subject to a combination of local and non-local wind action in the coastal region, and the river discharge into the lagoon (Möller et al., 1996; Vaz et al., 2006). Thus, transport and retention of fish eggs and larvae, and their consequent survival are susceptible to these forcing (Martins et al., 2007). Southerly winds promote salty water intrusion and transport of fish larvae into the estuary, whereas northerly winds promote freshwater runoff and export organisms from the estuary towards the coastal area (Möller et al., 1996; Martins et al., 2007). Thus, it can be hypothesized that the last scenario is not favourable for the development of the $M$. furnieri life cycle.

Studies on pelagic fish recruitment have shown the complexity of this subject, but little is known about how larvae respond to the processes controlling the estuarine dynamics, thus there is an intensive search for new techniques and tools to explore how the influence of hydrodynamic processes act on temporal and spatial scale (Vaz et al., 2007; Dias et al., 2014). A new tool to address the problem of fish eggs and larvae dispersion is the use of biophysical models, such as Individual-Based Models (IBMs) (Wernet et al., 2007).

The IBM basic concept is to consider a fish larvae as a unique and discrete individual, with their own biological attributes that evolve along their life cycle (Werner et al., 2007). The most common attributes are size, the location of spawning and weight (Grimm \& Railsback, 2005; Vaz et al., 2007). An IBM is initialized by coupling with a hydrodynamic model, which provi- des the environmental conditions to the biological model (Davis \& Lyne, 1994; Lyne \& Thresher, 1994; Doney et al., 2001; Lima et al., 2002; Mullon et al., 2002; Skogen et al., 2003; Adlandsvik et al., 2004; Sentchev \& Korotenko, 2004; Porobic et al., 2012).

The present study involves the development of an IBM for the early life stages of M. furnieri and its coupling with surface current velocity fields from TELEMAC-3D, to simulate transport and retention of eggs and larvae in the PLE. Thus, this study aims to address how the wind influences the transport of $M$. furnieri early stages into the PLE. The use of this approach will provide a further understanding of the influence of the coastal dynamics on the fish life cycle and provide new tools to study fish recruitment.

\section{MATERIALS AND METHODS}

\section{Study area}

The Patos Lagoon, located in the southernmost coast of Brazil $\left(30-32^{\circ} \mathrm{S}, 50-52^{\circ} \mathrm{W}\right)$, is the largest choked coastal lagoon in the world (Kjerfve, 1986) (Fig. 1), receiving tributaries that drain an area of approximately $201,700 \mathrm{~km}^{2}$ (Fernandes et al., 2002). These tributaries impose a seasonal runoff pattern that is common to mid-latitudes, with high discharges in winter and late spring, and low discharges during summer and autumn.

The estuarine region comprises about $1,000 \mathrm{~km}^{2}$, representing $10 \%$ of the total lagoon area (Costa et al., 2014), and is inhabited by diverse and abundant flora and fauna (Odebrecht et al., 2010). The lagoon is in a region with an average tidal influence of $0.23 \mathrm{~m}$ (Defant, 1961).

As the tidal amplitude is small, the combined effect of the wind and freshwater water contribution become important in controlling the dynamics of the system (Kjerfve, 1986; Kjerfve \& Magill, 1989). The mean freshwater discharge in the north of the Patos Lagoon is $2,500 \mathrm{~m}^{3} \mathrm{~s}^{-1}$. Moller et al. (2001) explained that when the freshwater discharge is larger than $3,000 \mathrm{~m}^{3} \mathrm{~s}^{-1}$, it controls the dynamics of the system, whereas, during smaller continental contributions periods, the wind effect becomes important (Möller et al., 2001; Fernandes et al., 2002). The combination of local and remote wind effects is determinant to establish the flood and ebb flows in and out of the PLE, resulting in variable estuarine limits (Odebrecht et al., 2010).

Summer and autumn are the periods of low discharge when onshore southerly winds force seawater through the inlet into the lower estuary and occasionally as far as $150 \mathrm{~km}$ into the lagoon. In contrast, northerly winds combined with high river discharge significantly reduce estuarine salinity (Martins et al., 2007). 


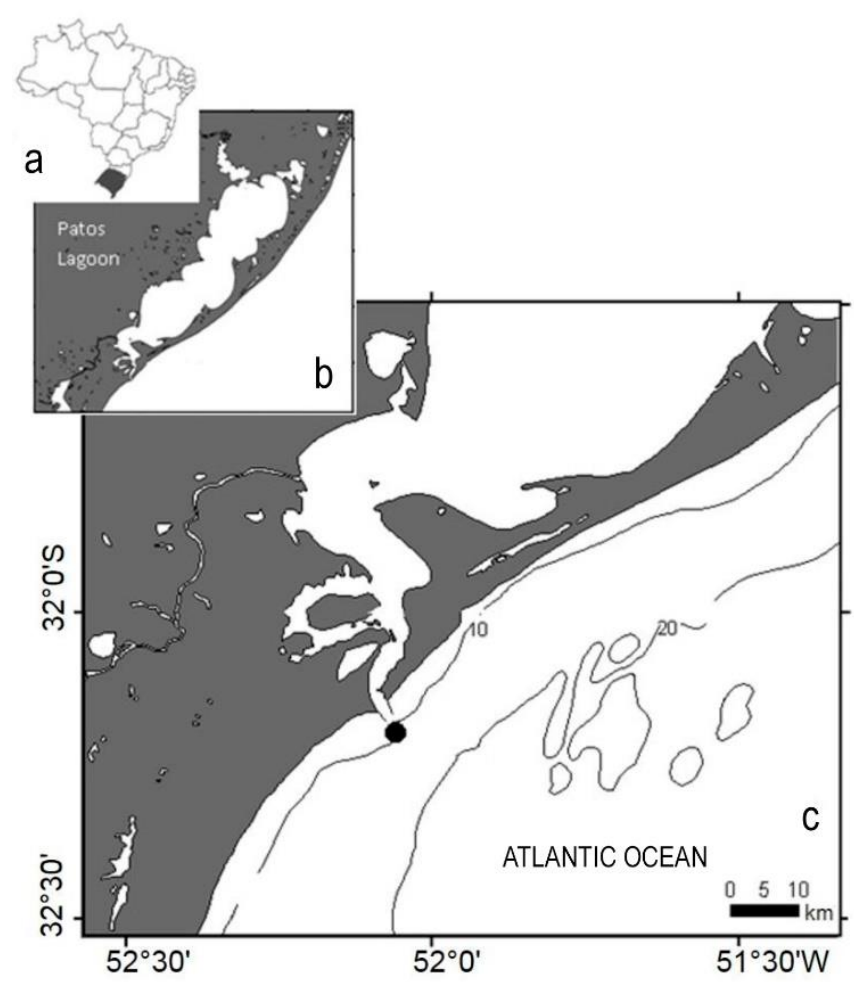

Figure 1. a) Rio Grande do Sul State, b) Patos Lagoon location and c) Patos Lagoon Estuary (PLE) and location of the initial spawning site $(\bullet)$ used in the IBM simulation.

\section{Hydrodynamic model}

The hydrodynamic module of the TELEMAC-3D System (http://www.opentelemac.org) was used to generate the velocity field at the surface. TELEMAC3D is a hydrodynamic model based on the Finite Elements Method, allowing a numerical mesh with a better refinement in regions of greatest interest and morphological variability, and lower resolution in regions where the morphology is more homogeneous, resulting in less computational time. The model uses a Cartesian reference system, in which the $\mathrm{x}$ and $\mathrm{y}$-axes form a horizontal plane and gravity acts in the vertical direction. Details about the model formulation and approximations are presented by Hervouet (2007).

The model domain used in this study extends from $28^{\circ} \mathrm{S}$ (Florianopolis, Brazil) to $36^{\circ} \mathrm{S}$ (Punta Del Este, Uruguay) and from $45^{\circ}$ to $54^{\circ} \mathrm{W}$, in order to better represent the coastal circulation in the area of interest. The representation of the Patos Lagoon bathymetry was obtained from a combination of bathymetric data from different nautical charts: 2140 (Patos Lagoon), 2101 (Rio Grande Harbour), 2102 (São José do Norte to Setia Channel), 2103 (Barra do Canal São Gonçalo to Porteiras), 2106 (Saco do Rincão) and 2112 (Rio Grande to Ponta da Feitoria). The lower PLE bathymetry was updated with data from surveys conducted by the Port of Rio Grande Authority.
The model domain was forced with initial (3D salinity fields) and boundary conditions obtained from different sources. Salinity, temperature and current velocity and direction were obtained from the global forecast model (Ocean Circulation and Climate Advanced Model-OCCAM, http://www.oceanmodeling.org). Wind data were obtained from the National Oceanic \& Atmospheric Administration-NOAA (www. cdc.noaa.gov/cdc/reanalysis). These data sets were interpolated from its original resolution to each node of the numerical mesh.

The tidal influence was prescribed at each nodal point of the oceanic boundary of the domain using the amplitude and phase of the five main tidal components of the study area: K1, M2, N2, O1, S2 (Fernandes et al., 2004), obtained from the Grenoble Model (FES95.2, Finite Element Solution v.95.2). The model was forced with the monthly discharges of Patos Lagoon, which corresponds to the simulated period $\left(1,000 \mathrm{~m}^{3} \mathrm{~s}^{-1}\right)$.

The TELEMAC-3D Model has been widely calibrated, validated and applied for hydrodynamic studies in the south coast of Brazil (Fernandes et al., 2002; Marques et al., 2009; Silva et al., 2015) and in order to verify the reproducibility of the model for the present case study we conducted additional cali-bration and validation simulations. These exercises were 
performed according to the availability of sea level rise and current velocity data for the period between April and May 2004 and the first 28 days of the simulation were used to stabilize the hydrody-namics of the model. The detailed information about these exercises is present in Marques et al. (2009). Results from the hydrodynamic simulation carried out between 1 January and 1 March 1998 produced the output velocity fields used to force the IBM simulations.

\section{Biological model}

The biological model used in this work was modified from Vaz et al. (2007) and adapted to the biological data from M. furnieri for the PLE and adjacent coastal region. The IBM generated simulations considering the trajectory of $M$. furnieri eggs and larvae from spawning to post-flexion larvae of $12 \mathrm{~mm}$ (30 days' simulation) and which was forced with output surface velocity fields from TELEMAC-3D. In this work, it was assumed that the velocity in the mixed layer was homogeneous and approximately equal to the surface velocity. Therefore, only surface velocity fields were used as inputs to the particle-tracking algorithm embedded in the IBM. Also, it considers the species growth estimated by the Laird-Gompertz model: $\mathrm{Cp}$ : $1.85 \mathrm{e}^{9.077(1-\mathrm{e}-0.008 \mathrm{t})}$ (Albuquerque et al., 2009) and the hatching was calculated by Pauly \& Pullin (1988): $\log$ $\mathrm{D}=7.1+0.608 \log \Phi-4.09 \log (\mathrm{T}+26)$, where $\Phi$ : egg diameter; t: temperature; D: days (Ibagy \& Sinque, 1995). Size at hatching was set at $1.85 \mathrm{~mm}$ and larvae were followed until $12 \mathrm{~mm}$ when they could actively search for their nursery grounds (Albuquerque et al., 2009). When larvae reach $12 \mathrm{~mm}$, their position and number are recorded, and the simulation is finished.

IBM simulations were conducted in January 1998 (summertime) when the highest abundance of eggs and larvae of $M$. furnieri occurs in the region and is considered the main spawning period for the species (Muelbert \& Weiss, 1991; Costa et al., 2014).

The IBM domain extends from $32^{\circ} 30^{\prime} \mathrm{S}$ to $51^{\circ} 20^{\prime} \mathrm{W}$, and the initial spawning site was located at the PLE mouth, near the $10 \mathrm{~m}$ isobath (between $32^{\circ} 11^{\prime} 24^{\prime \prime} \mathrm{S}$ to $32^{\circ} 12^{\prime} 0^{\prime \prime} \mathrm{S}$ ), with an area of $2.42 \mathrm{~km}^{2}$ (Fig. 1). Transport of $M$. furnieri eggs and larvae were analyzed only at the surface, where $\mathrm{U}$ and $\mathrm{V}$ velocity data were taken from the hydrodynamic model and interpolated to adjust the TELEMAC domain output to the IBM domain. The displacement of particles followed a Runge-Kutta spatial integration scheme of fourth-order (Sebastião \& Soares, 1995; Vaz et al., 2007), and turbulent movements of eggs and larvae were simulated using a random walk component (Vaz et al., 2007). The restrictions imposed to the IBM were the limits of the domain and the coastline; thus, the larvae that reached these areas were counted as lost from the model domain; the time step used in the IBM was of one hour.

The IBM simulation was composed of four events generated from the different wind patterns measured for January 1998 (Fig. 2). TELEMAC-3D simulations for the four events were used to analyze the transport and retention of M. furnieri eggs and larvae. In this analysis, we considered the first two events starting during periods of north winds followed by south winds, and the last two events were carried out during periods of south winds followed by northerly winds.

The time interval covering the events is shown in Table 1. For each event, the difference in eggs/larvae transport under the influence of sporadic wind events was analyzed. The number of released eggs at the initial time of simulation was set at 70,000 eggs as a commitment between computational constraints (Vaz et al., 2007) and actual egg density in the region (Ibagy $\&$ Sinque, 1995).

In event $1,27 \mathrm{~h}$ of northerly winds were followed by $12 \mathrm{~h}$ of winds from the south; in event 2 , northerly winds lasted $27 \mathrm{~h}$ and were followed by $40 \mathrm{~h}$ of southerly winds; in event 3 , after $30 \mathrm{~h}$ of southerly winds were followed by $12 \mathrm{~h}$ of northerly winds; and, in event $4,33 \mathrm{~h}$ of southerly winds were followed by 35 $\mathrm{h}$ of northerly winds.

\section{RESULTS}

The wind pattern during the simulation period indicated alternation between events of southern and northern wind conditions (Fig. 2). In event 1, eggs and larvae were exposed to northerly and then southerly winds. The maximum northerly wind velocity was $7 \mathrm{~m} \mathrm{~s}^{-1}$, and the maximum southerly wind velocity was $9 \mathrm{~m} \mathrm{~s}^{-1}$. Under northerly wind conditions, eggs and larvae were gradually displaced towards the south of the model domain (Fig. 3a), and only when the wind turned to southerly (Fig. 3b), larvae were transported towards the PLE and adjacent coastal zone (to north and south). In this condition the larvae reached approximately $20 \mathrm{~km}$ into the estuary, where is their nursery habitat.

In event 2, larvae were subject to wind from northern direction followed by southerly winds, but the intensity of southerly wind was less than in the first

Table 1. Selected simulation events based on wind patterns observed in January 1998.

\begin{tabular}{lcc}
\hline Event & Initial time (h) & Final time (h) \\
\hline Event 1 (E1) & 15 & 55 \\
Event 2 (E2) & 190 & 258 \\
Event 3 (E3) & 312 & 355 \\
Event 4 (E4) & 457 & 526 \\
\hline
\end{tabular}




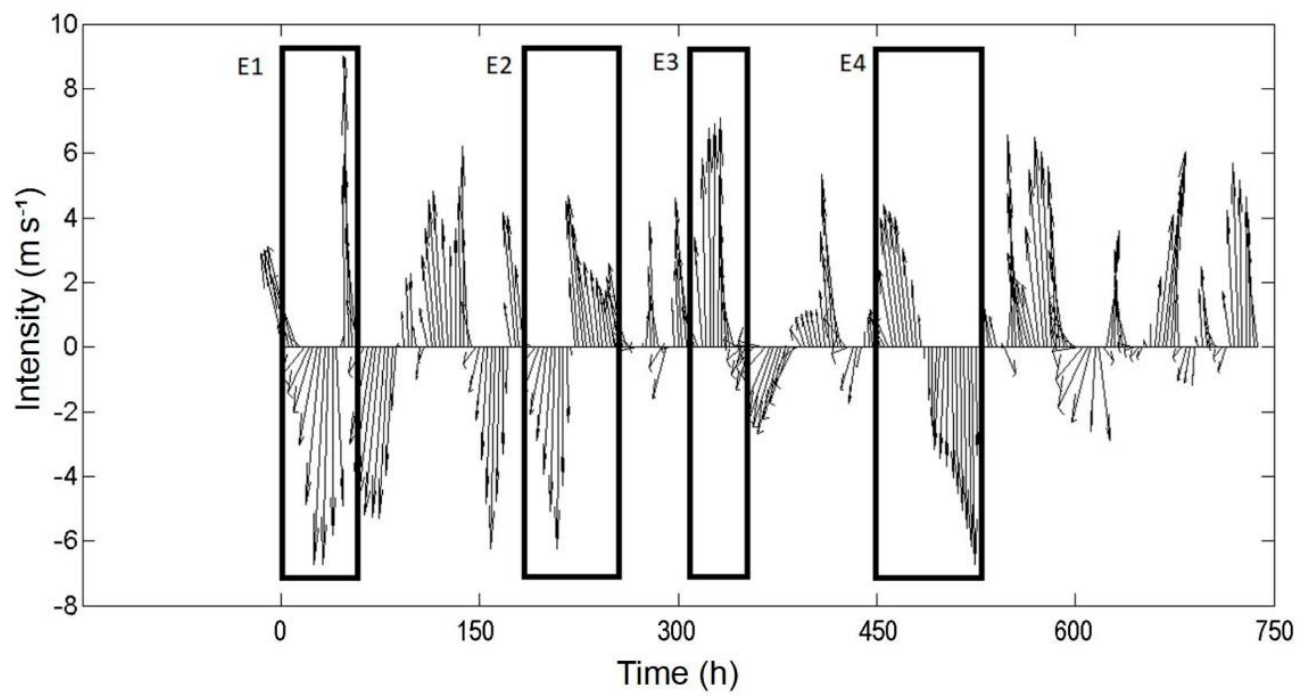

Figure 2. Wind intensity $\left(\mathrm{m} \mathrm{s}^{-1}\right)$ and direction during the 720-h simulation period (January 1998). Rectangles denote the time intervals used for each event of simulation with the biological model. Positive values represent southerly winds, and negative values represent northerly winds.
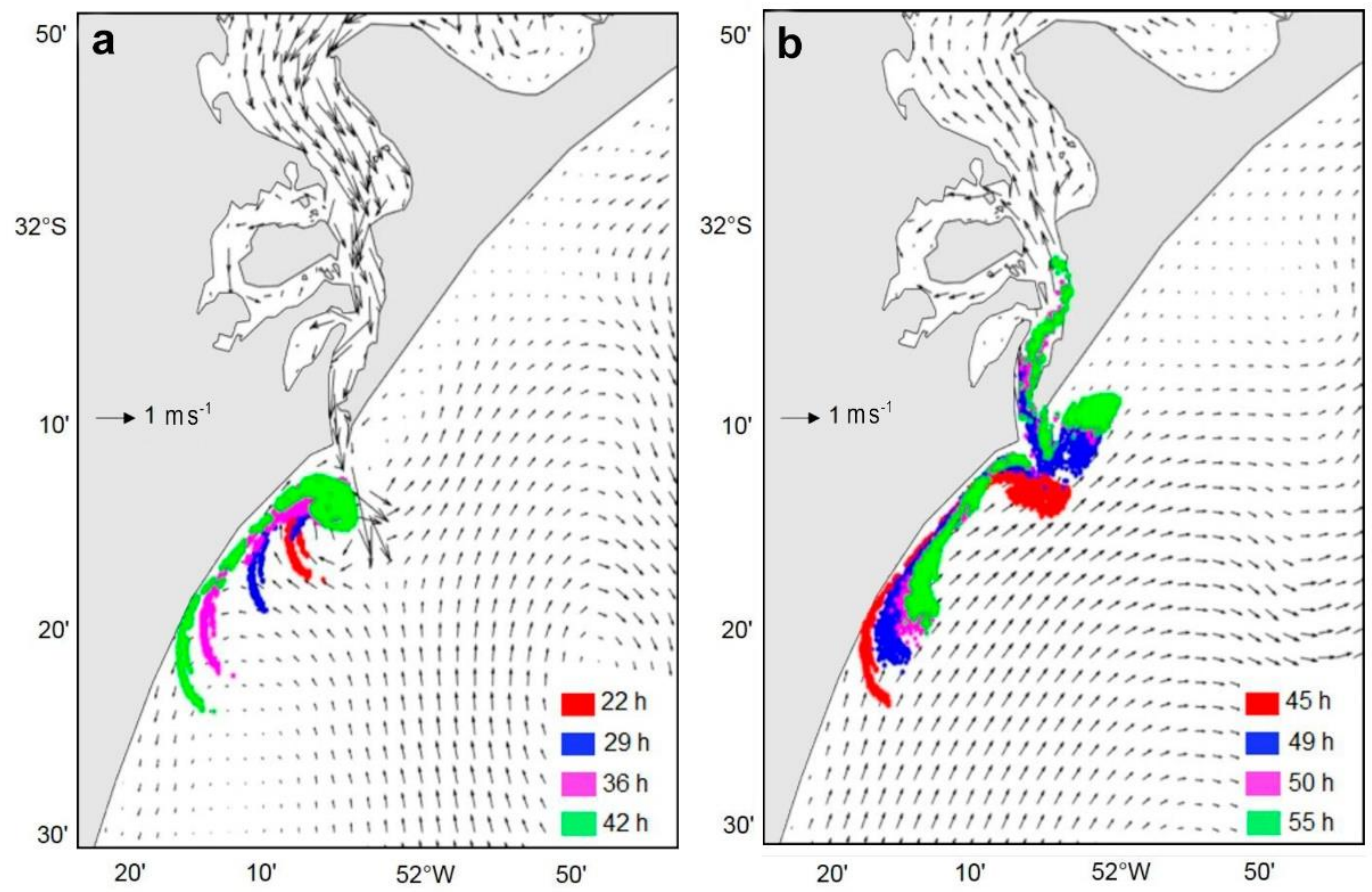

Figure 3. Distribution of Micropogonias furnieri eggs and larvae at different time intervals for each wind condition during event 1: a) incidence of northerly wind, b) southerly wind conditions. Black arrows are surface current velocity fields vectors $\left(\mathrm{m} \mathrm{s}^{-1}\right)$ for the duration of the wind condition.

event, even though the wind duration was higher than in the first event. The maximum northerly wind velocity was $6 \mathrm{~m} \mathrm{~s}^{-1}$, and the maximum southerly wind velocity was $5 \mathrm{~m} \mathrm{~s}^{-1}$. Under the influence of northerly winds, larvae were transported to the south of the domain (Fig. 4a), and some of them left the model domain in the last time step. When the wind turned to the south quadrant some of the larvae were transported back to a favorable zone for recruitment, but most larvae did not reach this zone (Fig. 4b).

In event 3 , the maximum wind velocity was $7 \mathrm{~m} \mathrm{~s}^{-1}$ from the south and $3 \mathrm{~m} \mathrm{~s}^{-1}$ from the north. Under the influence of southerly winds, a marked transport of larvae towards the PLE mouth was observed, where most 

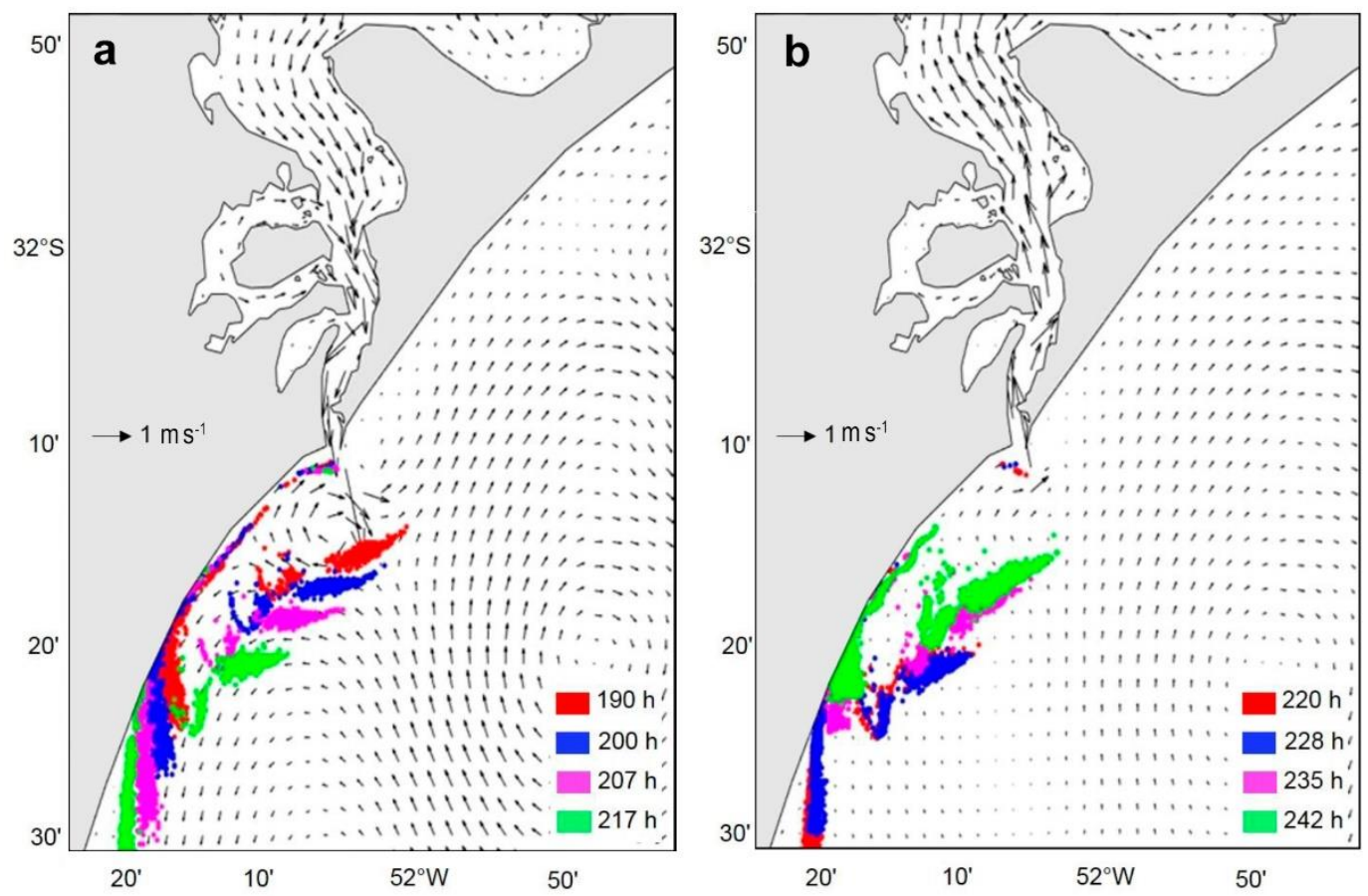

Figure 4. Distribution of Micropogonias furnieri larvae at different time intervals for each wind condition during event 2: a) incidence of northerly wind, b) southerly wind conditions. Black arrows are surface current velocity fields vectors (m $\mathrm{s}^{-1}$ ) for the duration of the wind condition.
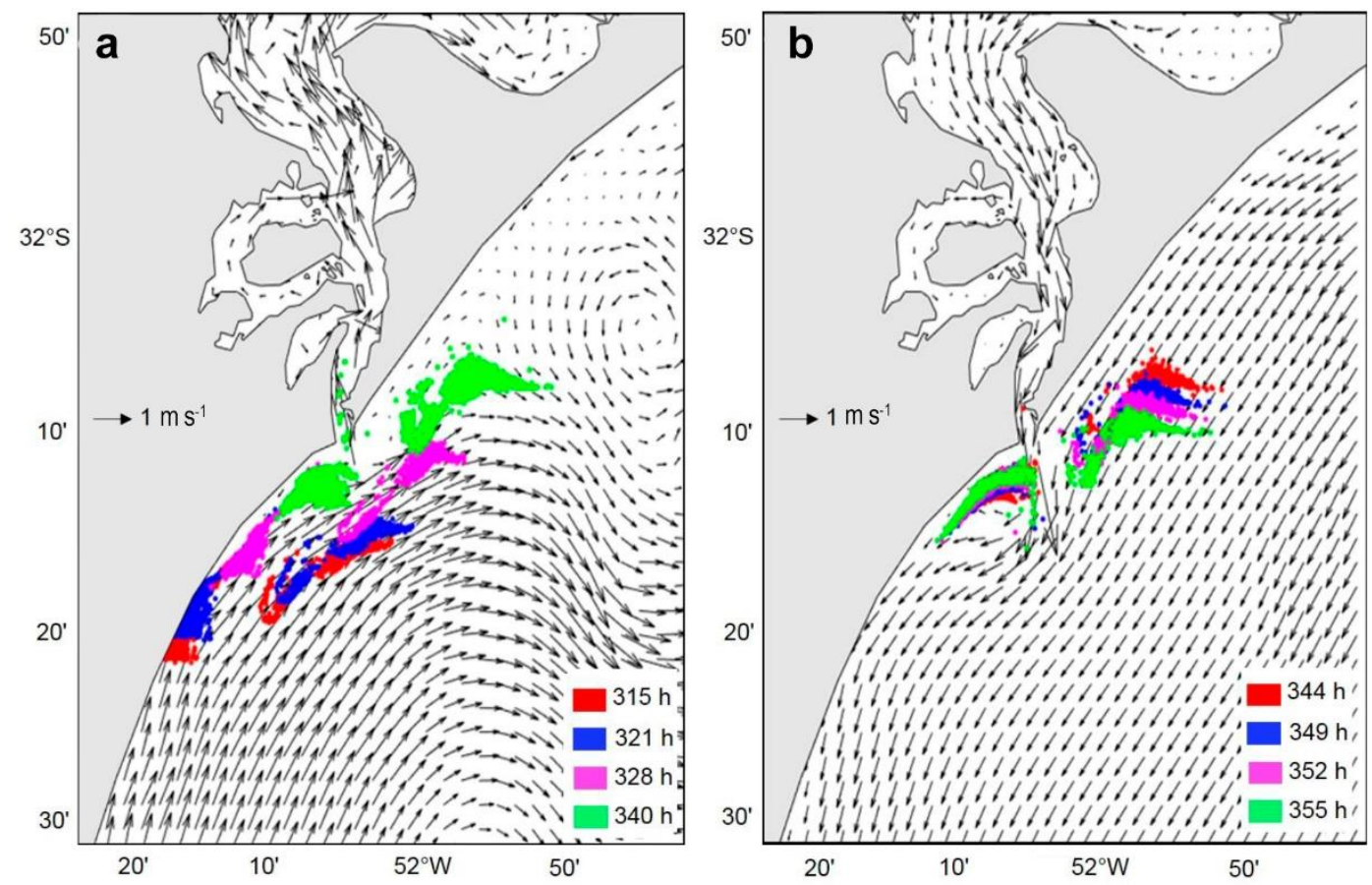

Figure 5. Distribution of Micropogonias furnieri larvae at different time intervals for each wind condition during event 3: a) incidence of southerly wind, b) northerly wind conditions. Black arrows are surface current velocity fields vectors (m $\mathrm{s}^{-1}$ ) for the duration of the wind condition.

of the larvae were retained close to favourable zones for recruitment (PLE and coastal zone) at the last time step (Fig. 5a). After the reversal to northerly winds, some of the larvae moved slightly away from the PLE, but many remained near the favourable recruitment zone, showing that the duration of the northerly wind was small and 

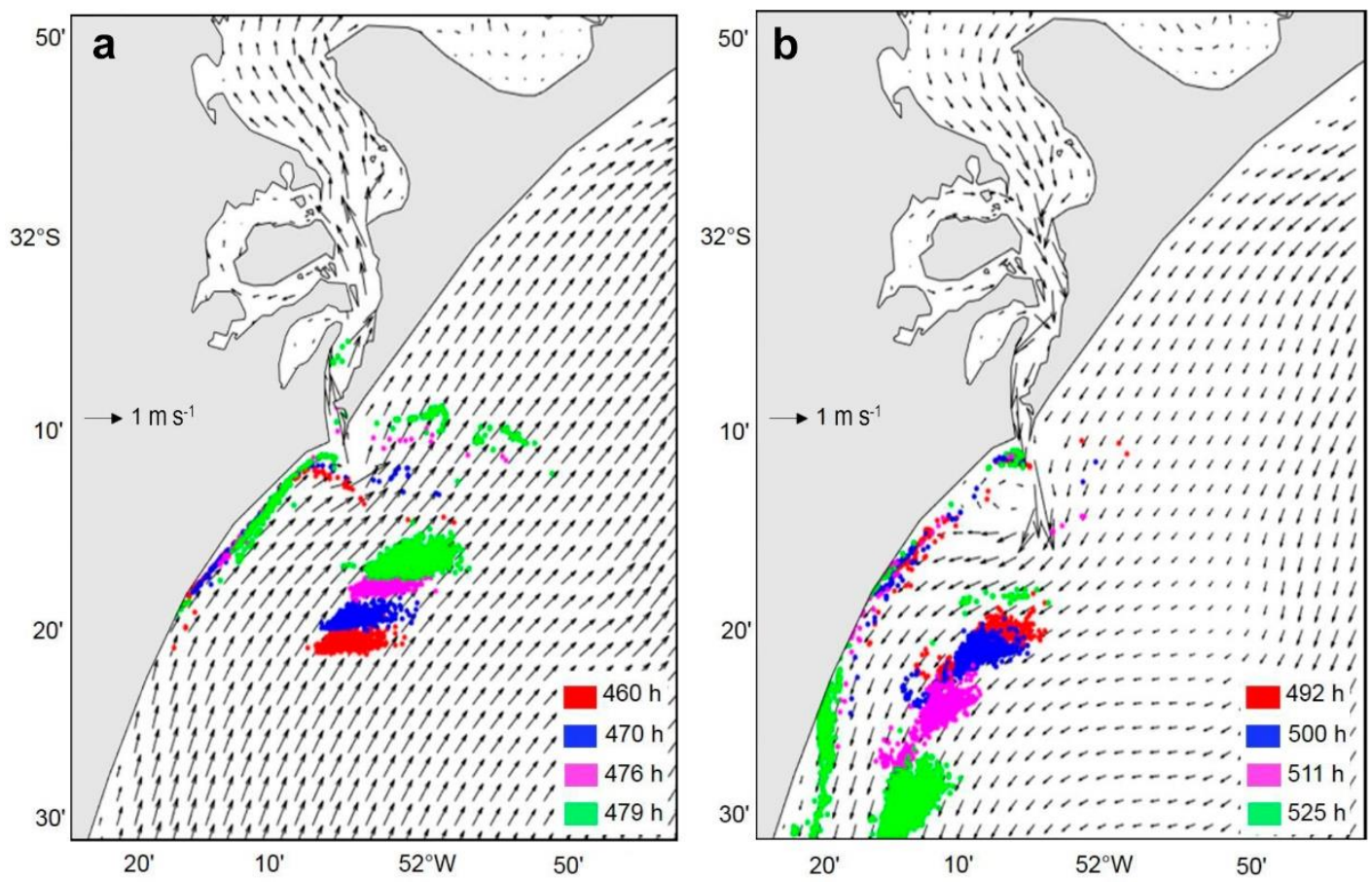

Figure 6. Distribution of Micropogonias furnieri larvae at different time intervals for each wind condition during event 4: a) incidence of southerly wind, b) northerly wind conditions. Black arrows are surface current velocity fields vectors (m $\mathrm{s}^{-1}$ ) for the duration of the wind condition.

insufficient to move the larvae back to the south (Fig. $5 b)$.

In event 4, larvae were subject to winds from the southern quadrant, followed by winds from the northern quadrant but with a longer duration than in the third event. The maximum southerly wind velocity was $5 \mathrm{~m} \mathrm{~s}^{-1}$, and the maximum northerly wind velocity was $7 \mathrm{~m} \mathrm{~s}^{-1}$. Under the influence of southerly winds, larvae were transported to the inner PLE, being distributed along the main channel, the estuary mouth and adjacent coastal zone (Fig. 6a). Some of the larvae entered the estuary and reached about $10 \mathrm{~km}$ landwards. Once the wind changed to the northern direction with a longer duration than in the previous event, the larvae that were inside the estuary were transported to adjacent coastal zone, but still remained near the mouth of the PLE and most of the larvae were distributed to the south and the north of the domain (Fig. 6b).

\section{DISCUSSION}

Previous studies in the region have shown that the combination of local and non-local wind effects and the freshwater discharge are the dominant factors forcing the water exchange between the lagoon and ocean (Möller et al., 1996; Fernandes et al., 2002, 2004), with tides playing a minor role in the estuarine dynamics
(Möller et al., 2001; Fernandes et al., 2002). Modelling results revealed the entrance and retention of larvae and the importance of southerly winds on the transport of larvae spawned at the mouth of the PLE.

Chiswell et al. (2003) have already recorded a positive relationship between the effect of a circulation pattern change and the effect in the transport of individuals to different zones (Cowen et al., 2006; Incze et al., 2010). Under the influence of southerly winds, Ekman transport acted towards the coast and favoured the retention of eggs and larvae in the coastal region. For this reason, $M$. furnieri that spawns at the mouth of the PLE is favored by this wind pattern, that promotes its entrance into the estuarine region (Figs. 3b, 4b, 5a, 6a). Vaz et al. (2007) observed that under the influence of southerly winds, Ekman transport also promoted the displacement of Engraulis anchoita to the coast. Moreover, Roman \& Boicourt (1999) concluded that shelf circulation induced by the wind at the Chesapeake Bay was an important mechanism for the dispersion and recruitment of crab larvae.

According to the results, it could be observed that the wind intensity, duration and direction are important for the transport of eggs and larvae to near or distant zones favorable to recruitment. The importance of the wind direction was also observed by Simionato et al. (2007) in the Río de la Plata estuary, where winds from 
southwest promoted higher retention of particles released at the surface near the estuary mouth. Martins et al. (2007) also found that the advective transport of eggs in the main channel towards the inner PLE is related not only to the intensity but also to the direction of the wind. Winds have also shown to be important in the transport of blue crab larvae in the Delaware Bay (Epifanio, 1995). It is noteworthy that the results demonstrating the importance of southerly induced Ekman transport for the recruitment of fish larvae to PLE may be underestimated by model constraints. The coastal boundary condition of the model considers that whenever a larva reached the coast, it was eliminated from simulation and considered lost. Thus, an overestimation of loss of larvae under conditions of southwest winds is created. The same condition was evidenced by Vaz et al. (2007).

Northerly winds favored larval dispersion along the continental shelf, and under this condition, Ekman transport was towards offshore and prevented organisms to enter the estuary. This pattern was also observed by Martins et al. (2007), who demonstrated that fish eggs did not enter the estuary under northeast wind conditions. Similarly, Simionato et al. (2008) found that northwest winds pushed the dispersion of particles of the salinity frontal zone and away from the Río de la Plata estuary mouth, retaining them in Samborombón Bay.

Wind direction and intensity are considered important components for egg and larval retention in other regions. Several species, such as Engraulis ringens in the northern Humboldt Current (Lett et al., 2007), E. anchoita in the southern Brazil continental shelf (Vaz et al., 2007) and E. encrasicolus in the Canary Islands (Brochier et al., 2008) rely on wind to complete their life cycle.

From the results of this work, it could be inferred the critical role of southerly wind patterns favoring the transport of eggs and larvae of $M$. furnieri to nursery habitat and the maintenance of its life cycle. Porobic et al. (2012) also related the significant impact of the hydrodynamic circulation to the development of the life cycle of the lobster (Jasus frontalis) on Juan Fernández Island's coastal zone, Chile.

The results obtained with the IBM forced with TELEMAC-3D output represent well the distribution of $M$. furnieri eggs and larvae in their environment and indicate that the present biophysical modeling is an adequate tool to study fish eggs and larvae transport under different wind conditions (direction, intensity and duration). Results showed that northerly winds are detrimental to the ingress of fish eggs and larvae in the estuary, while southerly winds favor transport towards nursery habitat and favorable recruitment areas.
Therefore, the incidence of southwest winds increases larval retention and represents favorable conditions for the recruitment of the M. furnieri in the PLE.

Although the IBM simulation was restricted to study the surface distribution of fish eggs and larvae, it revealed significant results about the influence of the circulation induced by winds in the PLE to M. furnieri transport. This unique experiment represents a significant step forward towards enhancing the current knowledge about the transport of important fisheries resources in this area. As future work, we suggest the use of a full 3D velocity field that will allow the simulation of sub-surface transport of eggs and larvae to improve our understanding of planktonic transport further and to study the differences between both approaches.

\section{ACKNOWLEDGMENTS}

We gratefully acknowledge support by the Brazilian government (Conselho Nacional de Desenvolvimento Científico e Tecnológico-CNPq) through the concession of grants. J.H.M. and E.H.F. received CNPq Grants (Proc. 310047/2016-1, Proc. 307602/2014-1, respectively). This study was partially funded by the Brazilian Long-Term Ecological Research Program (PELD) from CNPq (Proc.441492/2016-9), and the Fundação de Amparo à Pesquisa do Estado do Rio Grande do Sul (Proc. 16/2551-0000102-2).

\section{REFERENCES}

Abreu, P. \& Castello, J. 1997. Estuarine-marine interactions. In: Seeliger, U., Odebrecht, C. \& Castello, J.P. (Eds.). Subtropical convergence environments. Springer, Berlin, pp. 179-182.

Able, K.W. 2005. A re-examination of fish estuarine dependence: evidence for connectivity between estuarine and ocean habitats. Estuarine, Coastal and Shelf Science, 64: 5-17.

Adlandsvik, B., Gundersen, A.C., Nedreaas, J.K.H., Stene, A. \& Albert, O.T. 2004. Modeling the advection and diffusion of eggs and larvae of Greenland halibut (Reinhardtius hippoglossoides) in the north-east Arctic. Fisheries Oceanography, 13: 403-415.

Albuquerque, C.Q., Muelbert, J.H. \& Sampaio, L.A.N. 2009. Early developmental aspects and validation of daily growth increments in otoliths of Micropogonias furnieri (Pisces, Sciaenidae) larvae reared in the laboratory. Pan-American Journal of Aquatic Sciences, 4(3): 259-266.

Albuquerque, C.Q., Miekeley, N., Muelbert, J.H., Walther, B.D. \& Jaureguizar, B.D. 2012. Estuarine dependency 
in a marine fish evaluated with otolith chemistry. Marine Biology, 159: 2229-2239. doi: 10.1007/ s00227-012-2007-5

Beck, M.W., Heck, K.L., Able, K., Childers, W., Eggleston, D., Gillanders, D., Halpern, B.M., Hays, B., Hoshino, C., Minello, K.T., Orth, R., Sheridan, P. \& Weinstein, M. 2001. The identification, conservation, and management of estuarine and marine nurseries for fish and invertebrates. Bioscience, 51(8): 633-641.

Brochier, T., Ramzi, A., Lett, C., Machu, E., Berraho, A., Fréon, P. \& Hernández-León, S. 2008. Modelling sardine and anchovy ichthyoplankton transport in the Canary Current System. Journal of Plankton Research, 30: 1133-1146.

Castello, J.P. 1986. Distribución, crecimiento y maduración sexual de la corvina juvenil (Micropogonias furnieri) en el estuario de la "Lagoa dos Patos", Brasil. Physis, 44(106): 21-36.

Chao, L.N., Pereira, L.E. \& Vieira, J.P. 1985. The estuarine fish community of the Patos Lagoon, Brazil. A baseline study. In: Yáñez-Arancibia, A. (Ed.). Fish community ecology in estuaries and coastal lagoons: towards an ecosystem integration. Universidad Nacional Autónoma de México, Ciudad de México.

Chiswell, S., Wilkin, J., Booth, J. \& Stanton, B. 2003. Trans-Tasman Sea larval transport: is Australia a source for New Zealand rock lobsters? Marine Ecology Progress Series, 247: 173-182.

Costa. M.R. \& Araújo, F.G. 2003. Use of a tropical bay in southeastern Brazil by juvenile and subadult Micropogonias furnieri (Perciformes. Sciaenidae). ICES Journal of Marine Science, 60(2): 268-277. doi: 10.1016/S1054-3139(02)00272-2

Costa, M.D.P., Muelbert, J.H., Moraes, L.E., Vieira, J.P. \& Castello, J.P. 2014. Estuarine early life stage habitat occupancy patterns of white mouth croaker Micropogonias furnieri (Desmarest, 1830) from the Patos Lagoon, Brazil. Fisheries Research, 160: 77-84.

Cowen, R., Paris, C. \& Srinivasan, A. 2006. Scaling of connectivity in marine populations. Science, 311(5760): 522-527.

Davis, T.L.O. \& Lyne, V.D. 1994. Dispersal of the larval stage of southern bluefin tuna Thunnus maccoyii. In: Sammarco, P.W. \& Heron, M.L. (Eds.). The biophysics of marine larval dispersal. American Geophysical Union, Washington, pp. 137-148.

Defant, F. 1961. Physical oceanography. Volume II. Pergamon Press, London.

Dias, D.F., Pezzi, L.P., Gherardi, D.F.M. \& Camargo, R. 2014. Modeling the spawning strategies and larval survival of the Brazilian sardine (Sardinella brasiliensis). Progress in Oceanography, 123: 38-53.

Diaz, A.O., García, A.M., Figueroa, D.E. \& Goldemberg, A.L. 2008. The mucosa of the digestive tract in
Micropogonias furnieri: a light and electron microscope approach. Anatomia Histologia Embryologia, 37: 251-256.

D'Incao, F. 1991. Pesca e biologia de Penaeus paulensis na Laguna dos Patos, RS. Atlântica, 13(1): 159-169.

Doney, S.C., Lima, I., Lindsay, K., Moore, J.K., Dutkiewicz, S., Friedrichs, M.A.M. \& Matear, R.J. 2001. Marine biogeochemical modeling: recent advances and future challenges. Oceanography, 14(4): 93-107.

Epifanio, C.E. 1995. Transport of blue crab (Callinectes sapidus) larvae in the waters off Mid-Atlantic states. Bulletin of Marine Science, 57(3): 713-725.

Fernandes, E.H.L., Dyer, K.R., Möller, O.O. \& Niencheski, L.F.H. 2002. The Patos Lagoon hydrodynamics during an El Niño event (1998). Continental Shelf Research, 22: 1699-1713.

Fernandes, E.H.L., Tapia, I.M., Dyer, K.R. \& Möller, O.O. 2004. The attenuation of tidal and subtidal oscillations in the Patos Lagoon Estuary. Ocean Dynamics, 54: 348-359.

Franco, T.P., Albuquerque, C.Q., Santos, R.S., Saint'Pierre, T.D. \& Araújo, F.G. 2018. Leave forever or return home? The case of the white mouth croaker Micropogonias furnieri in coastal systems of southeastern Brazil indicated by otolith microchemistry. Marine Environmental Research, 144: 28-35. doi: 10.1016/j.marenvres.2018.11.015

Froese, R. \& Pauly, D. 2018. Fish Base. World Wide Web Electronic Publication. [www.fishbase.org]. Reviewed: 15 January 2018.

Garcia, A.M., Vieira, J.P. \& Winemiller, K.O. 2001. Dynamics of the shallow-water fish assemblage of the Patos Lagoon Estuary (Brazil) during cold and warm ENSO episodes. Journal of Fish Biology, 59: 12181238.

Grimm, V. \& Railsback, S.F. 2005. Individual-based modeling and ecology. Princeton University Press, Princeton.

Haimovici, M., Martins, A.S. \& Vieira, P.C. 1996. Distribuição e abundância de peixes demersais sobre a plataforma continental do sul do Brasil. Revista Brasileira de Biologia, 56(1): 27-50.

Hervouet, J.M. 2007. Hydrodynamics of free surface flows: modelling with the finite element method. John Wiley \& Sons, Chichester. doi:10.1002/9780470 319628.fmatter. Reviewed: 11 October 2017.

Ibagy, A.S \& Sinque, C. 1995. Distribuição de ovos e larvas de Sciaenidae (Perciformes-Teleostei) da região costeira do Rio Grande do Sul-Brasil. Arquivos de Biologia e Tecnologia, 38(1): 249-270.

Incze, L., Xue, H., Wolff, N., Xu, D., Wilson, C., Steneck, R., Wahle, R., Lawton, P., Pettigrew, N. \& Chen, Y. 
2010. Connectivity of lobster (Homarus americanus) populations in the coastal Gulf of Maine: part II. Coupled biophysical dynamics. Fisheries Oceanography, 19(1): 1-20.

Kjerfve, B. 1986. Comparative oceanography of coastal lagoons. In: Wolfe, D.A. (Ed.). Estuarine variability. Academic Press, Cambridge, pp. 63-81. doi: 10.1016/B978-0-12-761890-6.50009-5. Reviewed: 17 November 2017.

Kjerfve, B. \& Magill, K.E. 1989. Geographic and hydrodynamic characteristics of shallow coastal lagoons. Marine Geology, 88: 187-199.

Lasta, C.A. \& Acha, E.M. 1996. Cabo de San Antônio: su importancia en el patrón reproductivo de peces marinos. Frente Marítimo, 3: 39-46.

Lett, C., Peven, P., Ayón, P. \& Fréon, P. 2007. Enrichment, concentration and retention processes in relation to anchovy (Engraulis ringens) eggs and larvae distributions in the northern Humboldt upwelling ecosystem. Journal of Marine Systems, 64: 189-200.

Lima, I.D., Olson, D.B. \& Doney, S.C. 2002. Intrinsic dynamics and stability properties of size-structured pelagic ecosystem models. Journal of Plankton Research, 24(6): 533-556.

Lyne, D.V. \& Thresher, R.E. 1994. Dispersal and advection of Macruronus novaezelandiae (Gadiformes: Merluciidae) larvae off Tasmania: simulations of the effects of physical forcing on larval distribution. In: Sammarco, P.W. \& Heron, M.L. (Eds.). The biophysics of marine larval dispersal. American Geophysical Union, Washington, pp 109-136.

Marques, W.C., Fernandes, E.H.L., Monteiro, I., \& Möller, O.O. 2009. Numerical modeling of the Patos Lagoon coastal plume, Brazil. Continental Shelf Research, 29: 556-571.

Martins, I.M.S., Dias, J.M., Fernandes, E.H.L. \& Muelbert, J.H. 2007. Numerical modeling of fish eggs dispersion at the Patos Lagoon Estuary - Brazil. Journal of Marine Systems, 68: 537-555.

Möller, O.O., Castaing, P., Salomon, J.C. \& Lazure, P. 2001. The influence of local and non-local forcing effects on the subtidal circulation of Patos Lagoon. Estuaries, 24(2): 297-311.

Möller, O.O., Lorenzetti, J.A., Stech, J.L. \& Mata, M.M. 1996. The Patos Lagoon summertime circulation and dynamics. Continental Shelf Research, 16: 335-351.

Ministério da Pesca e Aquicultura (MPA). 2010. Boletim Estatístico da Pesca e Aquicultura, Brasil 2008-2009. Ministério da Pesca e Aquicultura, Brasil.

Muelbert, J.H. \& Weiss, G. 1991. Abundance and distribution of fish larvae in the channel area of the Patos Lagoon Estuary, Brazil. In: Hoyt, R. (Ed.). Larval fish recruitment and research in the Americas: proceedings of the thirteenth annual larval fish conference. NOAA Technical Report NMFS, 95: 4354.

Mullon, C., Cury, P. \& Penven, P. 2002. Evolutionary individual-based model for the recruitment of anchovy (Engraulis capensis) in the southern Benguela. Canadian Journal of Fisheries and Aquatic Sciences, 59(5): 910-922.

Odebrecht, C., Abreu, P.C., Copertino, M., Benvenuti, C.E., Muelbert, J.H., Seeliger, U. \& Vieira, J.P. 2010. The Patos Lagoon Estuary: biotic responses to natural and anthropogenic impacts in the last decades (19792008). In: Kennish, M.J. \& Paerl, H.W. (Eds.). Coastal lagoons: critical habitats of environmental change. CRC Press, Florida, pp. 438-459.

Pauly, D. \& Pullin, R.S.V. 1988. Hatching time in spherical, pelagic marine fish eggs in response to size. Environmental Biology of Fishes, 21(2): 261-271.

Porobic, J., Parada C., Ernst, B., Hormazábal, S.E. \& Combes, V. 2012. Modeling the connectivity of Juan Fernández rock lobster (Jasus frontalis), subpopulations through a biophysical model. Latin American Journal of Aquatic Research, 40(3): 613-632. doi: 103856/vol40-issue3-fulltext-11

Roman, M. \& Boicourt, W. 1999. Dispersion and recruitment of crab larvae in the Chesapeake Bay plume: physical and biological control. Estuaries, 22: 563-574.

Sebastião, P. \& Soares, C.G. 1995. Modeling the fate of oil spills at sea. Spill Science \& Technology Bulletin, 2: $121-131$.

Sentchev, A. \& Korotenko, K. 2004. Stratification and tidal currents effects on larval transport in the eastern English Channel: observations and 3D modeling. Environmental Fluid Mechanics, 4: 305-331.

Shaw, R.F., Rogers, B.D., Cowan, J.H. \& Herke, W.H. 1988. Ocean-estuary coupling of ichthyoplankton and nekton in the northern Gulf of Mexico. American Fisheries Society Symposium, 3: 77-89.

Silva, P.D., Lisboa, P.V. \& Fernandes, E.H. 2015. Changes in the fine sediment dynamics after the Port of Rio Grande expansion. Advances in Geosciences, 39: $123-127$.

Siminonato, C.G., Meccia, V.L., Guerrero, R.A., Dragani, W.C. \& Nuñez, M.N. 2007. Río de la Plata estuary response to wind variability in synoptic to intraseasonal scales: 2. Currents' vertical structure and its implications for the salt wedge structure. Journal of Geophysical Research, 112: C007005. doi: 10.1029/ 2006JC003815. Reviewed: 6 July 2017.

Simionato, C.G., Berasategui, A., Meccia, V.L., Acha, M. \& Mianzan, H. 2008. Short time-scale wind forced 
variability in the Río de la Plata Estuary and its role in ichthyoplankton retention. Estuarine, Coastal and Shelf Science, 76: 211-226. doi: 10.1016/j.ecss.2007. 07.031. Reviewed: 20 January 2018.

Sinque, C. \& Muelbert, J.H. 1997. Ichthyoplankton. In: Seeliger, U., Odebrecht, C. \& Castello, J.P. (Eds.). Subtropical convergence environments: the coast and sea in the Southwestern Atlantic. Springer-Verlag, Berlin, pp. 51-56.

Skogen, M.D., Shannon, F. \& Stiansen, J.E. 2003. Drift patterns of anchovy Engraulis capensis larvae in the southern Benguela, and their possible importance for recruitment. African Journal of Marine Science, 25: 37-47.

Vasconcellos, M. \& Haimovici, M. 2006. Status of white croaker Micropogonias furnieri exploited in southern Brazil according to alternative of stock discreetness. Fisheries Research, 80: 196-202.

Vaz, A.C., Möller, O.O. \& Almeida, T.L. 2006. Análise quantitativa da descarga dos rios e afluentes da Laguna dos Patos. Atlântica, 28(1): 13-23.

Vaz, A.C., Parada, C.E., Palma, E.D., Muelbert, J.H. \& Campos, E.J.D. 2007. Modeling transport and retention of Engraulis anchoita Hubbs \& Marini, 1935 (Clupeiformes, Engraulidae) early life stages along the Central Southwestern Atlantic Continental Shelf. PanAmerican Journal of Aquatic Sciences, 2(2): 179-190.
Vazzoler, A.E.A.M. 1991. Sintese de conhecimentos sobre a biologia da corvina, Micropogonias furnieri (Desmarest, 1823), da costa do Brasil. Atlântica, 13: 55-74.

Vieira, J.P. 2006. Ecological analogies between estuarine bottom trawl fish assemblages from Patos Lagoon (32S), Brazil, and York River (37N), USA. Revista Brasileira de Zoologia, 23(1): 234-247.

Vieira, J.P. \& J.P. Castello. 1997. Fish fauna. In: Seeliger, U., Odebrecht, C. \& Castello, J.P. (Eds.). Subtropical convergence environments. The coast and sea in the Southwestern Atlantic. Springer-Verlag, New York, pp. 56-61.

Volpedo, A. \& Cirelli, A. 2006. Otolith chemical composition as a useful tool for sciaenids stock discrimination in southwestern Atlantic. Scientia Marina, 70(2): 325-334.

Wernet, F.E., Cowen, R.K. \& Paris, C.B. 2007. Coupled biological and physical models: present capabilities and necessary developments for future studies of population connectivity. Oceanography, 23(3): 54-69.

Received: 12 March 2018; Accepted: 11 April 2019 